\title{
Dissemination of Aleurocanthus woglumi in citrus plants, its natural enemies and new host plants in the state of Rio de Janeiro, Brazil
}

\author{
Disseminação de Aleurocanthus woglumi em citros, seus inimigos naturais e novas plantas \\ hospedeiras no estado do Rio de Janeiro, Brasil
}

\section{Rodrigo Garcia Alvim ${ }^{\mathrm{I}}$ Elen de Lima Aguiar-Menezes ${ }^{\mathrm{II}}$ Aurino Florencio de Lima ${ }^{\mathrm{II}}$}

\section{ABSTRACT}

Aleurocanthus woglumi is an exotic pest, widely disseminated in Brazil, with a high preference for citrus plants, but with a polyphagous feeding habit. The contribution of the state of Rio de Janeiro in the Brazilian production of citrus fruits is small; however, there are still public policies that encourage citrus production in the state. In 2010, the appearance of this pest in Rio de Janeiro was confirmed in the municipality of Cachoeiras de Macacu. The objectives of this research were to evaluate the dissemination of $\boldsymbol{A}$. woglumi in this state, conduct a survey of new species of host plants, identify and evaluate the population of natural enemies present at two orchards that grow 'Tahiti' limes (Citrus latifolia) infested by the pest in Cachoeiras de Macacu, RJ, Brazil. In 19 municipalities, leaves of citrus and other species of plants presenting aleyrodid nymphs were collected, and yellow sticky traps were installed to capture adults for subsequent identification. At the 'Tahiti' lime orchards, the leaf collections were done to confirm the species of Aleyrodidae, and regarding $A$. woglumi, the natural enemies associated with this pest were collected directly from the infested plants. The results showed that A. woglumi is widespread in 12 municipalities. Three new host plants for A. woglumi were identified: Artocarpus heterophyllus (Moraceae), Pouteria caimito (Sapotaceae) and Struthanthus flexicaulis (Loranthaceae). In Cachoeiras de Macacu, a new species of parasitoid of A. woglumi nymphs was named: Encarsia pergandiella (Hymenoptera: Aphelinidae), while the insects in the Coccinellidae (Coleoptera) family have stood out as predators of this pest.

Key words: Aleyrodidae, citrus blackfly, geographical distribution, facultative host plants, biological control agents.

\section{RESUMO}

Aleurocanthus woglumi é uma praga exótica, amplamente disseminada no Brasil, com grande preferência pelos citros, mas com hábito alimentar polífago. A participação do estado do Rio de Janeiro na produção brasileira de citros é pequena; todavia, ainda ocorrem políticas públicas de incentivo à citricultura no Estado. Em 2010, a ocorrência dessa praga no estado do Rio de Janeiro foi confirmada no municipio de Cachoeiras de Macacu. Os objetivos deste trabalho foram avaliar a disseminação de A. woglumi nesse Estado, levantar novas espécies de plantas hospedeiras, identificar e avaliar a população de seus inimigos naturais presentes em dois pomares de lima-ácida (Citrus latifolia) 'Tahiti', infestados pela praga em Cachoeiras de Macacu, RJ, Brasil. Foram realizadas coletas de folhas de citros e de outras espécies de plantas com presença de ninfas de aleirodídeos em 19 municipios, e armadilhas adesivas amarelas foram instaladas para a captura de adultos, para posterior identificação. Nos pomares de lima-ácida, coletas de folhas foram feitas para confirmar a espécie de aleirodídeo e, em se tratando de A. woglumi, coletaram-se inimigos naturais associados a essa praga diretamente nas plantas infestadas. Os resultados mostraram que A. woglumi está disseminada em 12 municipios. Três novas espécies de plantas hospedeiras de A. woglumi foram identificadas: Artocarpus heterophyllus (Moraceae), Pouteria caimito (Sapotaceae) e Struthanthus flexicaulis (Loranthaceae). Em Cachoeiras de Macacu, uma nova espécie de parasitoide de ninfas de A. woglumi foi assinalada: Encarsia pergandiella (Hymenoptera: Aphelinidae), enquanto que os insetos representantes da família Coccinellidae (Coleoptera) se destacaram como predadores dessa praga.

Palavras-chave: Aleyrodidae, mosca-negra-dos-citros, distribuição geográfica, plantas hospedeiras facultativas, agentes de controle biológico.

\section{INTRODUCTION}

Aleurocanthus woglumi Ashby (Hemiptera: Aleyrodidae) is a pest of Asian origin

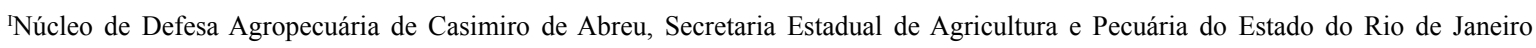
(SEAPEC-RJ), Casimiro de Abreu, RJ, Brasil.

IDepartamento de Entomologia e Fitopatologia, Universidade Federal Rural do Rio de Janeiro (UFRRJ), Rod. BR465, 23897-000, Seropédica, RJ, Brasil. E-mail: emenezes@ufrrj.br. "Corresponding author. 
and of considerable importance to citrus crops, which it is able to provoke a production loss of $80 \%$ (ASHBY, 1915; NGUYEN et al., 2013). The species is widely distributed throughout the world, including Brazil, and is commonly known as the citrus blackfly (EVANS, 2008; MAPA, 2015a). It was considered an A2 quarantine pest in Brazil, having been excluded from the list of these pests under the Normative Instruction of MAPA No. 42, on 9-DEC-2014, when it was already wide-spread in 20 of the 27 Brazilian states (ALMEIDA \& LHANO, 2014; MAPA, 2015b).

In Brazil, the citrus blackfly was first detected in the Northern region, specifically in the state of Pará (greater metropolitan area of Belém and neighboring municipalities) in 2001 (OLIVEIRA et al., 2001). In 2003 and 2004, this pest was recorded in the far western region of the Northeast, appearing in some municipalities in the state of Maranhão, where it was detected in citrus and mango crops (LEMOS et al., 2006). In 2008, it was recorded in the Southeast for the first time, in the state of São Paulo, also infesting these two types of fruit trees (SÁ et al., 2008), and in 2010, the first occurrence was recorded in Cachoeiras do Macacu, in the state of Rio de Janeiro. In 2012 this pest was detected in three more municipalities in the state of Rio de Janeiro, where it infested different citrus species (ALMEIDA \& LHANO, 2014).

The citrus blackfly has a polyphagous feeding pattern, with around 300 species in different botanical families recorded as host plants, with citrus (Citrus spp.) considered the most suitable host for developing large populations of this pest (EVANS, 2008; NGUYEN et al., 2013). In Brazil, on the list of plants with traffic restrictions between different states due to the identified presence of the citrus blackfly, there are 31 genera belonging to 23 botanical families (MAPA, 2015a). In every country where the blackfly installs itself, because of its versatility in adapting, it is able to find food sources in new hosts and survives in facultative host plants (FARIAS et al., 2011).

Ever since the citrus blackfly was recorded in Jamaica in 1913 (ASHBY, 1915), chemical insecticides have been used to control its infestation. However, the discovery of natural enemies associated with this pest has enabled the use of biological control (WHITE et al., 2005; EVANS, 2008).

Within this context, this research was conducted with the objectives of surveying the appearance of the citrus blackfly in other citrusproducing municipalities in the state of Rio de Janeiro, since the first notification in 2010, evaluating the occurrence of this pest's natural enemies in 'Tahiti' lime orchards, as well as the population of entomophagous insects that are present, and verifying the existence of other plant species as hosts of this pest.

\section{MATERIALS AND METHODS}

Survey of the citrus blackfly

Nineteen municipalities in the state of Rio de Janeiro were selected because of the presence of citrus fruit orchards and gardens that market citrus plants, with 12 municipalities in the central region (Cachoeiras de Macacu, Casimiro de Abreu, Guapimirim, Itaboraí, Magé, Niterói, Nova Iguaçu, Rio Bonito, Rio de Janeiro, São Gonçalo, Tanguá and Silva Jardim), two in the Northern region (Campos dos Goytacazes and Natividade), three in the mountain area (Cordeiro, Duas Barras and Nova Friburgo), one in the Northwestern region (Itaperuna) and one municipality in the Southern region (São José do Vale do Rio Preto).

Between January 2010 and December 2013, inspections were conducted to determine the occurrence of the blackfly in the gardens and orchards, using yellow sticky traps installed to collect adult Aleyrodidae. In these same locations, leaves from citrus plants and other types of plants that were infested with the nymphs of these insects were gathered, with the support of trained workers from the Coordenadoria de Defesa Sanitária Vegetal (CDSV) (Department of Sanitary Plant Protection) of the State Agriculture and Livestock Office of Rio de Janeiro (SEAPEC-RJ). The collected leaves were herborized, secured in paper envelopes duly identified with the information regarding the species of the host plant, place of collection, date and name of collector.

Traps and envelopes, inside clear plastic bags, were sent to the Entomology and Phytopathology Department (DEnF), Institute of Biological Sciences and Health, of the Universidade Federal Rural do Rio de Janeiro (UFRRJ), in order to determine definitively the identification of the species by specialists in Aleyrodidae. The identified insects were then deposited in the Costa Lima Entomology Collection (CECL) of the DEnF/ UFRRJ (Seropédica, RJ, Brazil).

Survey of citrus blackfly's natural enemies

This survey was conducted in 'Tahiti' lime orchards (Citrus latifolia Tanaka, Rutaceae) on two properties that had a high infestation of the citrus blackfly: an orchard belonged to Ms. Wanda (Wanda's orchard) (22॰35'30.23”S, 4244’43.12”W) and another orchard belonged to Mr. Kasuo (Kasuo's 
orchard) $\left(22^{\circ} 35^{\prime} 8.47^{\prime \prime} \mathrm{S}, 42^{\circ} 43^{\prime} 20.32^{\prime \prime} \mathrm{W}\right)$, located in the district of Papucaia, municipality of Cachoeiras de Macacu, RJ. Leaf samples from the 'Tahiti' lime plants infested with the citrus blackfly were collected from August 2012 to July 2013. During the months with less rain, when there was a higher incidence of the pest, the samples were collected every 15-20 days, and during the rainy season, every 30-40 days. Ten ripe leaves containing citrus blackfly eggs and nymphs in the four quadrants were collected from 10 plants (total of 400 leaves). Prior to leaves collecting, the presence of natural enemies was assessed (insects and other entomophagous organisms) was assessed on the leaves infested by this pest, using a $20 \mathrm{x}$ to $30 x$ pocket magnifying glass. The collected leaves were secured in clear plastic bags and sealed, then transported to the Nucleus of Agriculture and Cattle Raising Protection of Cachoeiras de Macacu belonged to $\mathrm{CDSV} / \mathrm{SEAPEC}-\mathrm{RJ}$, where they remained until the emergence of possible parasitoids of the citrus blackfly. At the end of this period, adults that emerged were sacrificed in a cold chamber and secured in $1.5 \mathrm{ml}$ Eppendorf tubes, with safe-lock and conical bottoms, containing aqueous solution of alcohol to $70 \%$, for later triage and identification by a taxonomist of the DEnF. The identified entomophagous insects were deposited at the CECL.

Assessment of the abundance of entomophagous insects

At the two orchards mentioned above, on each assessment date, the two categories of entomophagous insects were counted: parasitoids (adults) and predators (larvae and adults), besides other entomophagous invertebrate organisms such as spiders and mites (adults), and total number of these insects and organisms was recorded on each collection date and for the whole collection period (TN). The following abundances were determined: seasonal abundance (SAB), calculated as the total number of entomophagous insects and other organisms divided by the total number of samples obtained in the whole collection period, expressed in percentage; the specific abundance (SA), referring to the total number of samples (adults and larvae) collected of entomophagous insects and other organisms, and the relative abundance (RA\%), corresponding to the percentage of ample numbers in each category compared with the total sample numbers obtained during the whole collection period.

The measurements of kurtosis and coefficient of variation (CV\%) indicated that the data referring to the number of samples collected did not have a normal distribution, not even after converting the numbers into square root; therefore, the KruskalWallis test was applied with a 5\% level of significance. To compare the two orchards, the data regarding the total sample numbers (TN) and the seasonal abundance (SAB) underwent a t-test with a 5\% level of significance. The analyses were carried out using the computer program STATGRAPHICS Plus for Windows, version 4.1 (MANUGISTICS, 1997).

\section{RESULTS AND DISCUSSION}

Dissemination of the citrus blackfly.

From January 2010 to December 2013, the presence of the citrus blackfly was detected in 12 of the 19 municipalities that were being monitored. The presence of this pest was not detected in these seven municipalities (Campos dos Goytacazes, Cordeiro, Duas Barras, Itaperuna, Natividade, Nova Friburgo and São José do Vale do Rio Preto), neither from the gathering of leaves of citrus plants and other botanical species nor from the yellow sticky traps.

Since the notification of the first infestation site of the citrus blackfly in a 'Tahiti' lime orchard in the state of Rio de Janeiro in September 2010, in the municipality of Cachoeiras de Macacu (ALMEIDA \& LHANO, 2014), the dissemination of this pest was confirmed in a neighboring municipality (Tanguá) in the same year, by means of yellow sticky traps; within three years it had spread to ten other municipalities. In 2012, the appearance of the pest was recorded in the surrounding municipalities of Guapimirim, Itaboraí, Magé and Rio Bonito, by means of leaf gathering (ALMEIDA \& LHANO, 2014). In these municipalities the citrus blackfly was found in orchard businesses, nurseries and houseplants. In 2013, the citrus blackfly was found in citrus plants in household backyards in the municipalities of Niterói, São Gonçalo, Silva Jardim and Rio de Janeiro, but at the headquarters of SEAPEC-RJ in Niterói it was found on citrus and mango plants. ALMEIDA \& LHANO (2014) conducted a survey in 2012 in Silva Jardim, but did not detect any presence of this pest on the gathered leaves of the 'Tahiti' lime, at the properties that were visited. In the same year, the citrus blackfly was detected in the municipalities of Casimiro de Abreu and Nova Iguaçu, in nurseries and trucks selling seedlings, whereby the pest was colonizing citrus plants originating in the municipality of Dona Euzébia, in the state of Minas Gerais, Brazil. This occurrence had already been noticed in nurseries selling seedlings in the municipality of Cachoeiras de Macacu, increasing the suspicion that the introduction 
of the citrus blackfly in the state of Rio de Janeiro came from citrus seedlings originating in Minas Gerais. These results corroborated the statement of BARBOSA (2007) that the main way of spreading the citrus blackfly to distant locations is through the infested propagation material, mainly ornamental plants and fruit plants, being transported by people.

\section{Host plants}

Within the municipalities of Rio de Janeiro that had infestation sites, the citrus blackfly was detected on the leaves of the 'Tahiti' lime (C. latifolia), as well as on eight other botanical species: Mangifera indica L. (mango, Anacardiaceae), which with the former make up the two host plants more commonly found for this aleyrodid, being followed by Coffea arabica L. (Arabica coffee, Rubiaceae), Syzygium jambos (L.) Alston (mountain apple tree, Myrtaceae), Artocarpus heterophyllus Lam. (jackfruit tree, Moraceae), Eugenia uniflora L. (Surinam cherry, Myrtaceae), Malpighia glabra L. (acerola tree, Malpighiaceae), Pouteria caimito (Ruiz \& Pav.) (abiu tree, Sapotaceae), and Struthanthus flexicaulis (Mart. ex Schult. f.) Mart (mistletoe, Loranthaceae). These were found near citrus orchards with high infestation; the latter is a parasitic plant commonly found in citrus orchards of the region. Based on the list of host plants published by MAPA (2015a), three new plant species that are hosts to the citrus blackfly were identified in the state of Rio de Janeiro: abiu tree, mistletoe and jackfruit tree. Three more plant species may be added as hosts of this pest in all Brazil: Surinam cherry, mountain apple tree and acerola tree, even though these have already been identified as such in other countries (EVANS, 2008). These results reinforce the polyphagous habit of this aleyrodid (NGUYEN et al., 2013). The mountain apple tree, scientifically named Eugenia sp., was recorded as a host plant for the citrus blackfly in the state of Pernambuco (ATAÍDE et al., 2011). In Rio de Janeiro, 'Tahiti' lime leaves infested with citrus blackfly nymphs were collected in Cachoeiras de Macacu, Guapimirim and Rio Bonito, while in Tangá, this pest was infesting leaves of the 'Seleta' sweet orange [Citrus sinensis (L.) Osbeck] (ALMEIDA \& LHANO, 2014).

\section{Natural enemies}

This is the first record of Encarsia pergandiella Howard (Hymenoptera: Aphelinidae) associated with citrus blackfly nymphs infesting $\boldsymbol{C}$. latifolia, based on the records of EVANS (2008). This species was described as a parasitoid of the whiteflies, such as Bemisia tabaci Gennadius (ZHANG et al., 2014), including Brazil (DE SANTIS, 1981). However, more studies should be done to assure the $\boldsymbol{E}$. pergandiella parasitism on the citrus blackfly, due to the processes of vertical symbiontic interaction (KENYON \& HUNTER, 2007). Encarsia opulenta Silvestri and Amitus hesperidum Silvestri (Hymenoptera: Platigasteridae) have been cited as effective parasitoids in the biological control of the citrus blackfly (NGUYEN et al., 2013). According to WHITE et al. (2005), the release of E. opulenta in citrus orchards of Trinidad provided a population control of the citrus blackfly with more than $98 \%$ efficiency. Although the classic biological control might be a priority for controlling exotic pests, there are cases where there might be a conflict of interests as to importing natural enemies, due to a lack of knowledge regarding the action of these enemies upon the local entomofauna. With the appearance of autochthonous biocontrol agents, one might consider conservation biological control.

The predators found in the $\boldsymbol{C}$. latifolia orchards were identified on the family level due to the difficulty in species identification because the vast majority was in juvenile form. Larvae and pupae of predator ladybird beetles (Coleoptera: Coccinellidae) were reported, recorded in higher numbers than the other entomophagous organisms. Other predator insects that were found were juvenile forms of green lacewings (Neuroptera: Chrysopidae). Species of ladybird beetles and green lacewings were reported by EVANS (2008) as being predators of the citrus blackfly. ATAÍDE et al. (2011) observed the green lacewing Ceraeochrysa spp. as a predator of $\boldsymbol{A}$. woglumi in fruit trees in the state of Pernambuco.

\section{Abundance of entomophagous insects}

Juvenile forms of ladybird beetles and green lacewings were more abundant that the other organisms observed, and the larvae of the former were higher in number than the lacewings in both collection sites (Tables 1 and 2). This fact is also due to the manner of collecting biocontrol agents, which did not prioritize all the adult forms of the insects. The total number of insects (TN) obtained in the whole collection period was considered equal between both orchards, once the null hypothesis was not rejected by the t-test, in the same way as the mean seasonal abundance (SAB).

Number of coccinellid larvae (CL) at Wanda's orchard was significantly higher than the other variables, indicating that these are individuals with a larger presence in this orchard, appearing in 
greater numbers in October and December 2012. Statistical value of the Kruskal-Wallis test was high for the individuals collected at Wanda's orchard $(\mathrm{H}=30.8115)$ and the $\mathrm{p}$-value was 0.0000102051 (significant at the level of $1 \%$ of probability). These individuals represented more than $50 \%$ of the total number of other organisms collected at this site (RA\% referring to $\mathrm{CL}=53.40 \%$ ), while the chrysopidae larvae corresponded to $12.04 \%$ of the total number of the collected organisms (Table 1).

At Kasuo's orchard, the coccinellid larvae also stood out from the other organisms collected, with significantly higher numbers, appearing in greater number in October 2012, whose value was very near to what was collected at Wanda's orchard. The statistical value of the Kruskal-Wallis test was also considered high for the individuals collected at Kasuo's orchard $(\mathrm{H}=11.736)$ and the p-value was 0.0385895 (significant at the level of $5 \%$ of probability). The ladybird beetle larvae were relatively more abundant, representing $47.27 \%$ (RA\%) of the total number of the organisms collected (Table 2).

As to the specific abundance (SA), the total number of coccinellid larvae at Wanda's orchard was almost two times higher $(\mathrm{CL}=102)$ than at Kasuo's orchard $(\mathrm{CL}=52)$, while the total number of chrysopidae larvae collected was practically the same $(\mathrm{CHL}=23$ and 24 for Wanda's and Kasuo's, respectively), and the same occurred for the adult ladybird beetles. The Wanda's orchard has a large cultivation area for 'Tahiti' limes $\left(15,000 \mathrm{~m}^{2}\right)$ and larger trees, albeit with less densification between trees and wide spacing (space between trees of $10 \mathrm{~m} \times 15 \mathrm{~m}$ ), which might have favored a higher number of organisms, mainly the beneficial ones, in relation to Kasuo's orchard (space between trees of $5 \mathrm{~m} \times 4 \mathrm{~m}$, in an area of $6,000 \mathrm{~m}^{2}$ ), since both orchards have the same number of plants $(n=300)$. Another factor that might have contributed to this is the location of the orchard at Wanda's property, which is on flat terrain and protected from the wind by natural windbreaks and large-sized trees.

\section{CONCLUSION}

Aleurocanthus woglumi is present in 12 municipalities in the state of Rio de Janeiro, with new entries for Casimiro de Abreu, Magé, Niterói, Nova Iguaçu, Rio de Janeiro, São

Table 1 - Quantitative analysis of the predator insect community (Coccinellidae and Chrysopidae), parasitoids and other organisms found on the 'Tahiti' lime plants infested with Aleurocanthus woglumi at Wanda's orchard. Cachoeira de Macacu, RJ - 2012/2013.

\begin{tabular}{|c|c|c|c|c|c|c|c|c|}
\hline Collection date $(\mathrm{mm} / \mathrm{dd} / \mathrm{yy})$ & CL & CAD & CHL & CHAD & $\mathrm{P}$ & OTH & $\mathrm{TN}$ & $\mathrm{SAB}(\%)$ \\
\hline $08 / 09 / 12$ & 11 & * & 1 & * & 1 & 7 & 20 & 10.47 \\
\hline $09 / 05 / 12$ & 5 & 1 & 6 & * & 1 & 5 & 18 & 9.42 \\
\hline $09 / 28 / 12$ & 5 & $*$ & $*$ & * & $*$ & 4 & 9 & 4.71 \\
\hline $10 / 10 / 12$ & 1 & 2 & $*$ & $*$ & * & 5 & 8 & 4.19 \\
\hline $10 / 31 / 12$ & 21 & 1 & 7 & * & $*$ & 6 & 35 & 18.32 \\
\hline $11 / 14 / 12$ & 9 & 1 & 5 & $*$ & 1 & 2 & 18 & 9.42 \\
\hline $12 / 13 / 12$ & 28 & 1 & * & * & * & 2 & 31 & 16.23 \\
\hline $01 / 23 / 13$ & $*$ & * & 1 & * & 1 & 2 & 4 & 2.09 \\
\hline $02 / 20 / 13$ & $*$ & 1 & $*$ & * & * & * & 1 & 0.52 \\
\hline $03 / 18 / 13$ & 9 & $*$ & * & $*$ & * & $*$ & 9 & 4.71 \\
\hline $04 / 24 / 13$ & * & * & $*$ & * & * & * & $*$ & $*$ \\
\hline $05 / 08 / 13$ & 6 & * & $*$ & $*$ & 1 & 8 & 15 & 7.85 \\
\hline $05 / 21 / 13$ & 1 & * & * & * & * & 2 & 3 & 1.57 \\
\hline $06 / 13 / 13$ & * & * & 3 & 1 & * & 5 & 9 & 4.71 \\
\hline $07 / 30 / 13$ & 6 & 2 & ${ }^{*}$ & * & * & 3 & 11 & 5.76 \\
\hline SA & 102 & 9 & 23 & 1 & 5 & 51 & 191 & 100 \\
\hline $\mathrm{RA} \%$ & 53.40 & 4.71 & 12.04 & 0.52 & 2.62 & 26.70 & 100 & \\
\hline
\end{tabular}

$\mathrm{CL}=$ total number of coccinellid larvae, $\mathrm{CAD}=$ total number of coccinellid adults, $\mathrm{CHL}=$ total number of chrysopidae larvae, $\mathrm{CHAD}=$ total number of chrysopidae adults, $\mathrm{P}=$ total number of parasitoids, $\mathrm{OTH}=$ total number of other entomophagous organisms, TN=total number of individuals by date of collection and for the whole collection period, $\mathrm{SAB}(\%)=$ Seasonal abundance (percentage). SA=Specific abundance, RA\%=Relative Abundance (percentage). ${ }^{*}$ Absence of individual. 
Table 2 - Quantitative analysis of the predator insect community (Coccinellidae and Chrysopidae), parasitoids and other organisms found on the 'Tahiti' lime plants infested with Aleurocanthus woglumi at Kasuo's orchard. Cachoeira de Macacu, RJ - 2012/2013.

\begin{tabular}{|c|c|c|c|c|c|c|c|c|}
\hline Collection date (mm/dd/yy) & $\mathrm{CL}$ & CAD & CHL & CHAD & $\mathrm{P}$ & OTH & $\mathrm{TN}$ & $\mathrm{SAB}(\%)$ \\
\hline $08 / 09 / 12$ & 4 & * & * & * & 1 & * & 5 & 4.54 \\
\hline 09/05/12 & 4 & 1 & 11 & $*$ & $*$ & $*$ & 16 & 14.54 \\
\hline $09 / 28 / 12$ & $*$ & 1 & $*$ & * & * & 3 & 4 & 3.63 \\
\hline $10 / 10 / 12$ & 5 & * & $*$ & * & $*$ & * & 5 & 4.54 \\
\hline $10 / 31 / 12$ & 22 & $*$ & 3 & $*$ & $*$ & * & 25 & 22.72 \\
\hline $11 / 14 / 12$ & * & $*$ & 4 & * & $*$ & 3 & 7 & 6.36 \\
\hline $12 / 13 / 12$ & 5 & * & 1 & 1 & * & * & 7 & 6.36 \\
\hline $01 / 23 / 13$ & * & * & 2 & * & * & 1 & 3 & 2.72 \\
\hline $02 / 20 / 13$ & $*$ & * & $*$ & $*$ & * & * & $*$ & $*$ \\
\hline 03/18/13 & 6 & * & $*$ & * & * & 2 & 8 & 7.27 \\
\hline $04 / 24 / 13$ & 1 & 3 & $*$ & 1 & * & 7 & 12 & 10.9 \\
\hline $05 / 08 / 13$ & * & 1 & 3 & 1 & 3 & * & 8 & 7.27 \\
\hline $05 / 21 / 13$ & 2 & $*$ & $*$ & * & $*$ & 1 & 3 & 2.72 \\
\hline $06 / 13 / 13$ & * & $*$ & $*$ & * & 1 & * & 1 & 0.96 \\
\hline $07 / 30 / 13$ & 3 & 2 & $*$ & * & * & 1 & 6 & 5.47 \\
\hline SA & 52 & 8 & 24 & 3 & 5 & 18 & 110 & 100 \\
\hline $\mathrm{RA} \%$ & 47.27 & 7.27 & 21.82 & 2.73 & 4.55 & 16.36 & 100 & \\
\hline
\end{tabular}

$\mathrm{CL}=$ total number of coccinellid larvae, $\mathrm{CAD}=$ total number of coccinellid adults, $\mathrm{CHL}=$ total number of chrysopidae larvae, $\mathrm{CHAD}=$ total number of chrysopidae adults, $\mathrm{P}=$ total number of parasitoids, $\mathrm{OTH}=$ total number of other entomophagous organisms, $\mathrm{TN}=$ total number of individuals by date of collection and for the whole collection period, $\mathrm{SAB}(\%)=$ Seasonal abundance (percentage). $\mathrm{SA}=\mathrm{Specific}$ abundance, RA\% $\%$ Relative Abundance (percentage). ${ }^{*}$ Absence of individual.

Gonçalo and Silva Jardim. Three new species of host plants for $\boldsymbol{A}$. woglumi have been recorded: Pouteria caimito, Struthanthus flexicaulis and Artocarpus heterophyllus. For the first time the associaion of Encarsia pergandiella acting as a parasitoid of $\boldsymbol{A}$. woglumi nymphs infesting Citrus latifolia leaves has been identified. The insects Coccinellidae (Coleoptera) and Chrysopidae (Neuroptera) stand out in the natural biological control of $\boldsymbol{A}$. woglumi in $\boldsymbol{C}$. latifolia orchards, the former being predominant.

\section{ACKNOWLEDGEMENTS}

We wish to thank the Post-Graduate Program in Phytosanitary and Applied Biotechnology (PPGFBA) for the opportunity to carry out this research as part of the dissertation of the first author, as well as the Department of Sanitary Plant Protection (CDSV) for allowing us to divulge the results of the citrus blackfly survey in the state of Rio de Janeiro, conducted by its trained technicians.

\section{REFERENCES}

ALMEIDA, M.C.; LHANO, M.G. Occurrence of Aleurocanthus woglumi Ashby, 1915 (Hemiptera: Aleyrodidae) at Rio de Janeiro State. Revista Agro@mbiente On-line, v.8, n.3, p.424-427, 2014. Available from: $<$ http://revista.ufrr.br/index.php/agroambiente/article/viewFile/1897/1437>. Accessed: July 18, 2015
ASHBY, S.F. Notes on diseases of cultivated crops observed in 1913-1914. Bulletin of the Department of Agriculture, v.2, p.299-327, 1915.

ATAÍDE, M.L. et al. Ocorrência de Aleurocanthus woglumi e predação por Ceraeochrysa spp. em fruteiras no Estado de Pernambuco. In: SIMPÓSIO DE CONTROLE BIOLÓGICO, 12., 2011, São Paulo, SP. Resumos... São Paulo: Sociedade Entomológica do Brasil, 2011. p.205. Available from: $<$ http://seb. org.br/eventos/SINCONBIOL2011/PDF/PT0261.pdf > . Accessed: June 03,2016

BARBOSA, F.R. Pragas de risco da mangicultura no Brasil. In: SIMPÓSIO DE MANGA DO VALE DO SÃO FRANCISCO, 2., 2007, Juazeiro, BA. Anais... Petrolina: Embrapa Semi-Árido, 2007. (Documentos, 198). Available from: $<\mathrm{http}: / /$ ainfo.cnptia. embrapa.br/digital/bitstream/CPATSA/36031/1/OPB1369.pdf>. Accessed: June 03, 2016.

DE SANTIS, L. Sobre dos especies de Encarsia (Hymenoptera: Aphelinidae) del Brasil parasitoides de Bemisia tabaci (Homoptera: Aleyrodidae). Revista Brasileira de Entomologia, v.25, p.37-39, 1981

EVANS, G. The whiteflies (Hemiptera: Aleyrodidae) of the world and their host plants and natural enemies. Versão 2008. Beltsville: USDA, 2008. 703p. Available from: <http://www. sel.barc.usda.gov:8080/1 WF/World-Whitefly-Catalog.pdf $>$. Accessed: Oct. 05, 2013.

FARIAS, P.R.S. et al. Occurrence of Aleurocanthus woglumi Ashby in an area reforested with African mahogany in eastern Amazonia. Revista de Ciências Agrarias, v.54, n.1, p.85-88, 
2011. Available from: <http://doi.editoracubo.com.br/10.4322/ rca.2011.042>. Accessed: June 03, 2016. doi: 10.4322/ rca.2011.042.

KENYON, S.G.; HUNTER M.S. Manipulation of oviposition choice of the parasitoid wasp, Encarsia pergandiella, by the endosymbiotic bacterium Cardinium. Journal of Evolutionary Biology, v.20, n.2, p.707-716, 2007. Available from: <http:// onlinelibrary.wiley.com/doi/10.1111/j.1420-9101.2006.01238.x/ epdf>. Accessed: Oct. 05, 2013. doi: 10.1111/j.14209101.2006.01238.x.

LEMOS, R.N.S. et al. Occurrence of Aleurocanthus woglumi Ashby (Hemiptera: Aleyrodidae) in the State of Maranhão, Brazil. Neotropical Entomology, v.35, n.4, p.558-559, 2006. Available from: <http://www.scielo.br/pdf/ne/v35n4/31338.pdf >. Accessed: Oct. 05, 2013. doi:10.1590/S1519-566X2006000400021.

MANUGISTICS. Statgraphics Plus for Windows (version 4.1). Rockville: Maryland, 1997. 1 CD-ROM.

MAPA (MINISTÉRIO DA AGRICULTURA, PECUÁRIA E ABASTECIMENTO). Instrução Normativa No. 59, de 18 de dezembro de 2013. Available from: $<$ http://www.agricultura.gov.br/arq editor/file/Aniamal/Laborat $\% \mathrm{C} 3 \%$ B3rios/BACKUP-LAB/ESCOPOS/ IN\%2059-2013\%20-\%20pragas\%20quarenten $\% \mathrm{C} 3 \% \mathrm{~A} 1$ rias $\% 20$ para $\% 200 \% 20$ Brasil.pdf $>$. Accessed: July 17, $2015 \mathrm{a}$.

MAPA (MINISTÉRIO DA AGRICULTURA, PECUÁRIA E ABASTECIMENTO). Instrução Normativa No. 42, de 2 de dezembro de 2014. Available from: $<$ http://www.idaf.es.gov.br/
Download/Legislacao/DDSIV/Instru\%C3\%A7\%C3\%A30\%20 Normativa $\% 20$ n $\%$ C2\%BA $\% 20042 \% 20$ de $\% 2009 \% 20$ de $\% 20$ dezembro\%20de\%202014.pdf>. Accessed: Nov. 28, 2015 b.

NGUYEN, R. et al. Citrus blackfly, Aleurocanthus woglumi Ashby (Homoptera: Aleyrodidae). Gainesville: Florida Department Agriculture \& Consumer Service, Division Plant Industry, 2013. 4p.

OLIVEIRA, M.R.V. et al. MNC Aleurocanthus woglumi: alerta quarentenário. Brasília: Ministério da Agricultura, Pecuária e Abastecimento, 2001. 12p.

SÁ L.A."N. et al. Mosca-negra-dos-citros Aleurocanthus woglumi Ashby (Hemiptera: Aleyrodidae) em culturas de citros e de mangueira no estado de São Paulo e observações de sua biologia e controle. Jaguariúna: Embrapa Meio Ambiente, 2008. 4p. (Comunicado Técnico, 45).

WHITE, G.L. et al. Classical biological control of the citrus blackfly Aleurocanthus woglumi by Amitus hesperidum in Trinidad. BioControl, v.50, n.5, p.751-759, 2005. Available from: <http://link.springer.com/article/10.1007/s10526-005-09247>. Accessed: July 17, 2015. doi: 10.1007/s10526-005-0924-7.

ZHANG, Y.B. et al. Host selection by the autoparasitoid Encarsia pergandiella on primary (Bemisia tabaci) and secondary (Eretmocerus mundus) hosts. Insect Science, v.22, n.3, p.110, 2014. Available from: <http://onlinelibrary.wiley.com/ doi/10.1111/1744-7917.12152/pdf $>$. Accessed: July 17, 2015. doi: 10.1111/1744-7917.12152. 